\title{
Towards Renewable Energy Development in EU Region: Analyzing Feasibility of $100 \%$ Renewable Energy System for 2050 - Case Study of Cyprus
}

HUMPHREY ADUN ( $\square$ humphreyadun@gmail.com )

Cyprus International University: Uluslararasi Kibris Universitesi

\section{Peter ISHAKU}

Cyprus International University: Uluslararasi Kibris Universitesi

\section{MOEIN Jazayeri}

Cyprus International University: Uluslararasi Kibris Universitesi

\section{MUSTAFA DAGBASI}

Cyprus International University: Uluslararasi Kibris Universitesi

\section{BAMISILE OLUSOLA}

Cyprus International University: Uluslararasi Kibris Universitesi

TOCHI OKOYE

Cyprus International University: Uluslararasi Kibris Universitesi

\section{Research Article}

Keywords: Critical excess electricity, ENERGYPLAN, Renewable energy sources, Power plants, carbon dioxide emission.

Posted Date: February 22nd, 2022

DOl: https://doi.org/10.21203/rs.3.rs-1308562/v1

License: (c) (i) This work is licensed under a Creative Commons Attribution 4.0 International License. Read Full License 


\section{Abstract}

Cyprus continues to be one of the European Union's most energy import-dependent countries. It is of worthy note that Cyprus is also the only EU member state whose electricity grid is not connected to the European power network, as it uses an independent network that relies on local production. Furthermore, in a bid to meet the European Union target of $40 \%$ renewable energy electricity generation, Cyprus needs to fully utilize the vast renewable energy potential in the region. In this study, the integration of dominant renewable energy sources (solar, wind, and concentrated solar power) to the thermal power run grid system is simulated. Also, a $100 \%$ renewable energy electricity generation for 2050 is also modelled. The analysis is done, for a projected 8.3TWh/year of electricity demands, in the ENERGYPLAN simulation environment. The deterministic factors considered in this study are the power production and critical excess electricity production. Eight (8) case scenarios were developed in this study for comparative discourse of most feasible electricity generation to cut down on carbon dioxide emission in Cyprus. The optimized analysis reveals that the best case scenario for electricity generation for 2050 is PV system integrated with the oil powered plants. This system (PV/Oil) would generate 1.68TWh/year of renewable energy electricity. For $100 \%$ renewable energy electricity generation, the most feasible option is the PV/Wind/storage system. This system would have an installed 4000MW PV capacity, 7500MW wind capacity and 30GWh storage capacity.

\section{Introduction}

The European region have, over the years, employed diversification of energy resources in trying to resolve the overarching challenge of rising dependence of energy imports and increasing greenhouse gas emissions. Some key issues highlighted by the European Commission relating to energy sector in the region include (Van Wees, Uyterlinde, \& Maly, 2002)

- a clear structure for matching local energy in a nation with energy policies

- the internal energy market (gas and electricity directives) including improvement of Trans-3 European Energy Networks

- emergency arrangements, notably establishing 90 days of mandatory oil stocks

- social and regional consequences of restructuring the solid fuel sector

- structuring of nuclear energy safety standards

- Improving energy efficiency and increasing the production of the use of renewable energy.

As a result, the European Commission has launched a series of long-term low-carbon policy objectives and has looked into pathways to reduce GHG emissions in important sectors including power and transportation. Regarding promoting the use of renewable energy, there is a common target in the European Union of increasing the share of RE in final energy consumption (Ćosić, Krajačić, \& Duić, 2012). The "White Paper for a Community Strategy and Action Plan, Energy for the Future: Renewable Sources of Energy" was adopted by the European Commission in December 1997 (1996a, 1997) (Harmelink, Voogt, \& Cremer, 2006). By 2010 , the goal was to expand the usage of renewable energy sources (RES) to $12 \%$ of total inland energy consumption in the European Union (EU) (del Río, 2017). The target for 2020 included a 20\% cut in 
greenhouse gas emissions (from 1990 levels), adoption of 20\% RES, and 20\% improvement in energy efficiency. In driving RE production and increasing energy conservation in the European Union, several efficient policies have been proposed. This has led to increase in RE share in electricity generation, growing from 14.8-25.4\% between 2005 and 2013 (Eurostat, 2015), largely tied to rise in investment in solar and wind energy. The Renewable energy sources for electricity (RES-E) Directive for 2010 and for 2020, arguably, have aided in the broadening and acceleration of an already existing trend in numerous countries by leveraging strong growth in renewable energy production (OECD/ILO, 2019; Spencer, Colombier, \& Ribera, 2013). However, due to the disparity in renewable energy consumption in the European region, the Renewable energy directive (2009/28/EC) was revised. The new directive (2018/2001), which took effect from December 2018, employs the European Union to increase RE production to $30 \%$ by 2030 , as compared to the 1990 levels. Among the European Union members, the highest share of RE is in Finland, with $41 \%$. Latvia, Denmark, and Austria follow with high RE integration of $39 \%, 36 \%$, and $33 \%$ respectively (EC, n.d.). Luxembourg (6\%), the Netherlands and Malta (7\%), Belgium (9\%), Cyprus and the United Kingdom (10\%), on the other hand, had the lowest percentage of renewables (EC, n.d.). Some of the reasons for the disparity in the transition to renewable energy in the European states is that not all countries commenced the transition from similar position, and also they have differing levels of facilities (technological status). Furthermore, the location of energy generation: local or imported, constitute a crucial basis in the pathway towards RE energy transition. It is worth noting that in the EU, about $45 \%$ of the energy generated is sourced locally, while $55 \%$ is imported. Most of the countries with slower transitioning to high scale RE generation, is usually tied to extensive use of energy imports. More action is required, particularly in countries that rely heavily on energy imports. High-energy-importing countries like Cyprus should face less capacity restrictions in pursuing a more aggressive transition to renewables, and they should be more motivated as a result of rising energy price volatility (Kahia, Aïssa, \& Lanouar, 2017).

In European states, all sectors, with the exception of transportation, have already cut their emissions in comparison to 1990 levels. On a worldwide (IEA, 2012b) and European (Eurostat, 2013) scale, the transportation industry, which accounts for around $20 \%$ of total emissions (IEA (International Energy Agency), 2012), is still expanding its greenhouse gas emissions (GHG). Therefore, the transport sector also constitute an essential component to achieving GHG emission reductions, as currently a quarter of Europe's GHG emissions is produced from this sector. The road transport having a share of $70 \%$ in the total transport GHG emissions, point to the need for green road transport means in low carbon mobility (Xu, Yilmaz, Wang, Poganietz, \& Jochem, 2020). The EU has set a target of reducing the GHG emissions from transport by $54 \%$ in 2050 (Otter, 2018). One of the approaches to achieve this target is the use of electric vehicles (EV), which include battery electric vehicles (BEV) and plug-in hybrid electric vehicles (PHEV) (Plötz, Schneider, Globisch, \& Dütschke, 2014). It is worth stating that the incorporation of EVs in the transport sector have the potential of significantly cutting down emissions, as they will unsettle the dominance of fossil fueled cars (Khaligh \& $\mathrm{Li}, 2010)$. Even though their indirect emissions may be significant, European regulation nevertheless considers BEVs to be zero-emission vehicles (Jochem, Babrowski, \& Fichtner, 2015). Several researchers have studied the integration of grid system in Europe. Hartmann and Özdemir (Hartmann \& Özdemir, 2011) in their study considered three different scenarios for charging electric vehicles in German grid in 2030.. Their study concluded that there will be an estimated $89 \%$ availability of passenger cars in Germany that 
can be plugged into the grid system. Also, it was measured that maximum daily revenue of V2G activities (vehicle to grid) activities was $0.68 E_{2009}$. A study by Fernandez (Fernández, 2021) considered the feasibility of uncontrolled electric vehicle charging from the grid at a specific time in Spain. Their analysis reported a spike in the daily demand of electric power and peak consumption, which would be unmanageable. Their study suggested that to efficiently implement electro-mobility in Spain, vehicle charging should be done during working hours.

Considering the promotion of renewable energy is gaining priority in the EU for its contribution to security and diversification of supply, for environmental protection (including climate change abatement), and for reasons of social and economic cohesion, the mobilization of low carbon pathways (through renewable electricity, and V2G would support the carbon footprint reduction of EU nations). The potential transition to 100\% local energy production by 2050 in Latvia was discussed in a study by Porubova (Porubova \& Bazbauers, 2010). The $100 \%$ renewable energy integration into the Latvian grid system was estimated to be feasible in the condition that there is $20 \%$ increase in primary energy demand by 2050, relative to 2008 demand. The utilization of Biomass resources which has over 30 TWh annual resource capacity was stated to play a significant role for electricity and heat production. An important conclusion mentioned in their study was that for $100 \%$ self-sufficient energy production, the Latvian energy system cannot only depend on renewable energy systems which are economically feasible in the short term (like Biomass), but rather must those systems which are economically less attractive in the short run(like wind power, and solar photovoltaics (PV)). In a similar vein, different strategies of future renewable energy integration into the Portuguese grid was analyzed by Liliana et al. (Fernandes \& Ferreira, 2014). Their study constructed three (3) reference scenarios: scenario 1 being based on year 2020, with inclusion of wind, hydro, and PV power plants, scenario 2 being based on forecast of year 2022, which rely heavily on higher electricity consumption, and scenario 3 being based on a 100\% RE target electricity production. In the 100\% RE, their study considered PV system, wind power, wave energy, and hydropower. Their result showed that the share of RES in the total electricity was $55 \%, 68 \%, 82 \%$ and $100 \%$ for the reference scenario, scenario 1 , scenario 2 , and scenario 3 respectively. Their study conclusively stated that a 100\% RES was theoretically achievable, however, it would lead to a significant increase in the total capacity of the system, to ensure no shortfall during the periods of low RES availability. Steps towards 100\% RE integration for electricity, heat and transport sector in Ireland was modelled by Connolly et al. (Connolly, et al. 2011). Their study simulated four 100\% renewable energy scenarios: scenario 1 was a biomass energy system (BES), scenario 2 was hydrogen energy system (HES), scenario 3 was electricity from RE (EES), and scenario 4 was a combination of BES, HES, and EES scenarios.

Cyprus continues to be one of the European Union's most energy import-dependent countries. It is of worthy note that Cyprus is also the only EU member state whose electricity grid is not connected to the European power network, as it uses an independent network that relies on local production (Demetriou, Mallouppas, \& Hadjistassou, 2021). The source of electricity production in the country is $91 \%$ from diesel and heavy fuel oil. Furthermore, the emission from electricity and transportation sector in Cyprus accounts for $47 \%$ and $30 \%$ (67\% from vehicles) of the total emission respectively. In cooperation with the EU vision to reduce GHG emissions, Cyprus has set reduction target of 42\% GHG targets by 2030 (Cyprus Department of Environment Seventh national communication \& third biennial report, 2018). Meanwhile, Cyprus has a lot of solar energy 
potential, as well as some wind and biomass energy (Mesimeris, Kythreotou, Partasides, \& Piripitsi, 2019). Solar water heating systems are used by $92 \%$ of residences and $53 \%$ of hotels. According to a survey conducted by the European Union, Cyprus is a pioneer in the field of solar thermal applications, having built around $1 \mathrm{~m}^{2}$ of collector area per capita (Alexopoulos \& Hoffschmidt, 2010).

Several studies exist in literature regarding renewable integration in grid system, as a veritable resource in the discourse of the EU resolution to meet the GHG reduction targets. However, there is a lack of research attention in countries with high importation of energy, like Cyprus, as this factor affects the transition to $100 \%$ RES. This study presents 8 scenarios for renewable energy future of Cyprus based on RES integration in electricity and transportation.

The current state of the energy system in Cyprus is carried out using the Energy PLAN program. This study intends to focus on renewable energy integration in electricity and transportation, as this would serve as a sustainable pathway to reduce the high GHG emissions in the power and transportation sectors. To the best knowledge of the authors, no previous study have investigated different scenarios of combinations of renewable energy sources, and $100 \%$ renewable energy. Furthermore, this study aims to discuss the technical and economic feasibility of renewable energy in Cyprus, and also policies that can ensure penetration of RE in the grid system. Despite the fact that the article concentrates on Cyprus, many of the conclusions are applicable to other Central and Eastern European candidate nations, especially those with high energy imports as the impediments to optimum renewable energy integration, as well as the requirements for EU membership, are largely the same.

\section{Energy Situation in Cyprus and Need for Renewable Energy Integration}

The location of Cyprus is set in the north-eastern segment of the Mediterranean Sea, at $33^{\circ} \mathrm{E}$, and $35^{\circ} \mathrm{N}$ of the equator. Covering an estimated area of $9251 \mathrm{~km}^{2}$, with $1733 \mathrm{~km}^{2}$ covered with forests, Cyprus is the third biggest Mediterranean island, behind Sicily and Sardinia. The energy situation in Cyprus is one that demands crucial analysis especially upon the context of renewable energy development. The Island, is heavily dependent on fossil fuels imported from neighboring countries. The Fig. 1 shows the total energy supply for Cyprus in 2019 (IEA, 2021b). It is seen that $89 \%$ of its energy is sourced from Oil, and coal accounts for approximately $1 \%$ of its energy supply. Solar energy $(5 \%)$ is the only renewable energy source harvested in Cyprus for meeting electricity demands. According to a study by (Koroneos, Fokaidis, \& Moussiopoulos, 2005), it was stated that Cyprus utilizes $62 \%$ of its export earnings for covering the oil importation cost. Table 1 reveals that the import of primary energy (oil) increased from 98068 TJ in 2013 to $112590 \mathrm{TJ}$ in 2018, which represents a $14.8 \%$ increment. This is tied to the increase in the energy demand on the Island. It is worth noting that the electricity consumption in Cyprus was $16793 \mathrm{TJ}$ in 2019, which represented the highest energy consumption by source, aside oil (IEA).

\section{Electricity situation in Cyprus}

Considering that Cyprus lacks primary energy sources, the Electricity Authority of Cyprus (EAC) relies only on imported fuel, primarily heavy fuel oil, to generate electricity. The EAC currently owns and operates three 
power plants (Table 2) with a combined installed capacity of $1478 \mathrm{MW}$ ((EAC), 2021). The thermal efficiency of all power plants, particularly those with $60 \mathrm{MW}$ fuel oil powered steam boiler units, are low. The efficiency of these units may be as low as $31 \%$, having a direct impact on the total power system's economic operation.

Table 1

Primary energy trade in Cyprus (2013 and 2018) (E. Profile, 2008)

\begin{tabular}{|llll|}
\hline & $\mathbf{2 0 1 3}$ & $\mathbf{2 0 1 8}$ & \% Increase \\
\hline Imports (TJ) & 98068 & 112590 & $14.8 \%$ \\
\hline Exports (TJ) & 0 & 0 & 0 \\
\hline Net trade (TJ) & -98068 & -112590 & $-14.8 \%$ \\
\hline Imports (\% Supply) & 125 & 123 & \\
\hline Exports (\% Production) & 0 & 0 & 0 \\
\hline Net trade (USD million) & -1529 & -1023 & $33.09 \%$ \\
\hline Net trade (\% of GDP) & -6.4 & -4.0 & $37.5 \%$ \\
\hline
\end{tabular}

Table 2

Cyprus Power station capacity ((EAC), 2021)

\begin{tabular}{|lll|}
\hline Power stations & Generating Units & Capacity \\
\hline Vasilikos & $3 \times 130 \mathrm{MW}$ Steam Units & $390 \mathrm{MW}$ \\
\cline { 2 - 3 } & $1 \times 38 \mathrm{MW}$ Open Cycle Gas Turbine & $38 \mathrm{MW}$ \\
\cline { 2 - 3 } & $2 \times 220 \mathrm{MW}$ Combined Cycle Gas Turbine Units & $440 \mathrm{MW}$ \\
\hline Dhekelia Power Station & $6 \times 60 \mathrm{MW}$ Steam Units & $360 \mathrm{MW}$ \\
\cline { 2 - 3 } & $2 \times 50 \mathrm{MW}$ Internal Combustion Units & $100 \mathrm{MW}$ \\
\hline Moni Power Station & $4 \times 37.5 \mathrm{MW}$ Open Cycle Gas Turbines & $150 \mathrm{MW}$ \\
\hline & Total Installed Capacity & $1478 \mathrm{MW}$ \\
\hline
\end{tabular}

Cyprus' electrical grid has similar issues to that of other large Mediterranean islands such as Crete and Malta. Excessive load growth associated with the commercial sector during the tourist season, low annual load factor with corresponding high peak demand, environmental restrictions associated with the development of new fossil-fired thermal power plants, and high-voltage transmission lines, which are limited if non-indigenous energy sources are used and isolated from large interconnected power grids. Figure 2 reveals that between 1990 and 2020, the electricity consumption have remarkably increased by $152 \%$ (IEA, 2021a). This increase is attributed largely to the exponential growth in the influx of tourists in the Island, and also the improvement in the standard of living of the populace. 


\section{Argument for Renewable energy production in Cyprus}

Apart from the European Union target for renewable energy production for European states (as discussed in the introduction section), which places a responsibility on the government for renewable energy production, several uniquely prevailing issues in the Cyprus energy scenarios creates a huge demand for renewable energy. The trend of increasing electricity demand is bound to continue: as the EAC has estimated an average of $6 \%$ annual electricity demand. This will mean that the cost of importation will also increase, and could have negative impact on the economic state of the Island. The need for energy independency and energy security is crucial for the state of the Island. Furthermore, the meteorological service of Cyprus have reported increased temperature on the Island over the years. There has been a cumulative increase of $0.5^{\circ} \mathrm{C}$ in temperature on the island during the last century, as well as a $12 \%$ decrease in rainfall across the entire island, causing severe water shortage situations (Serghides, Dimitriou, \& Katafygiotou, 2016). Therefore, based on the report of international energy bodies that electricity production has the most influence on carbon dioxide emissions, it is safe to conclude that increasing the share of renewable energy sources in Cyprus will play a significant role in $\mathrm{CO}_{2}$ reduction and tackling the prevalent water shortage issue. Conclusively, in the case of the RE production, there is also a political point of view to consider. The negotiations for Cyprus and ten other Central and Eastern European countries began on March 31, 1998, when the interested parties signed an agreement for the EU's entry terms. Cyprus joined the EU as a full member in 2003. The comparison of European standards to Cyprus regulations in the energy sector was one of the most crucial steps in the negotiations. The goal will be to identify the differences that need to be addressed so that Cyprus' legislation on this subject is in line with European Union norms. Promoting renewable energy production and increasing energy efficiency is one of the European Union's top priorities in terms of energy policy. The EU has prepared a 'White Paper (Energy for the future: renewable sources of energy. White paper for a community strategy and action plan;COM (97) 599., n.d.)' for the specific topic of RES, which outlines the commission's RES strategy. The fundamental target of the 'White Paper' was for renewable energy to account for 12 percent of total energy production by 2010. To achieve this goal, member states must take steps to facilitate RES access to the energy market and accelerate the implementation of new or current RES technologies.

\section{Renewable Energy Situation In Cyprus}

Given the electricity isolation in Cyprus, the country has been making concerted efforts in creating more energy efficient future, in terms of development of renewable energy sources. Currently (2021), the renewable energy production in Cyprus stands at 157.5 MW of wind energy, 125MW from solar energy, and 12.8 MW from Biomass. Cyprus, surpassed the 13\% renewable energy production target under the EUmandated project, as by 2018 , Cyprus had installation of $13.8 \%$ RES. The country had set a target of installing an additional $360 \mathrm{MW}$ by 2023, and increase RES penetration in the electricity sector to $750 \mathrm{MW}$ (utilizing majorly solar energy) (International Trade Association, n.d.). This target is achievable and can be surpassed considering the vast renewable energy resource in the country. It is of worthy note that Cyprus has the highest potential for solar power among all the European Union countries, and it already has the highest solar water heater utilizations (per capita) for domestic use. It is estimated that $90 \%$ and $50 \%$ of 
residential and hotels respectively are equipped with solar water heaters (C. Profile, n.d.). An assessment of all available renewable energy sources discussed in the next section would provide a picture of the percentage of energy needs that could be met. Solar energy and wind energy are the two renewable energy sources that have the potential to be used economically and on large scale in Cyprus (Agathokleous, R. A., \& Kalogirou, 2020).

\section{Solar energy}

Cyprus experiences 340 days sunshine in a year, as every parts of the country enjoys a mild climate with lots of sunny days. In the six-month hot season, Cyprus has about 12 hours of bright sunshine daily, and about 6 hours of sunshine hours per day during the cold season (Fig. 3). The cloudiest periods on the high mountains during the winter season still experience, on average, about 4 hours of bright sunshine daily, which shows the abundance of solar energy resource in the country. The average daily global solar radiation varies from $2.3 \mathrm{kWh} / \mathrm{m}^{2}$ in the cloudiest months of the year (December and January), to $7.2 \mathrm{kWh} / \mathrm{m}^{2}$ in July (Michaelides, J. M., \& Votsis, 1991). The value for the annual global horizontal solar irradiation is between 1716 and $2008 \mathrm{KWh} / \mathrm{m}^{2}$, as shown in the Fig. 4.

Solar energy, despite its abundance in Cyprus, is widely and exclusively used in domestic hot water system application. There is presently no commercial application of solar energy sources. Furthermore, despite substantial cost reductions, with a $25 \%$ cost reduction in the last five years, solar electricity is hardly fulfilled on the island in terms of photovoltaics. This study views this situation as limitation in the country s effort in creating a more independent energy scenario. A model will be developed in this study that would simulate a scenario of $100 \%$ solar energy technologies (using photovoltaics, and concentrated solar power), to assess the technical and economic output of such practical design in future energy development in Cyprus.

\section{Wind energy}

Western or south western surface winds dominate in winter and northwestern or northern surface winds dominate in summer (Pashardes \& Christofides, 1995). They are usually light to moderate in strength, rarely reaching gale force. Winds are quite diverse in direction over Cyprus, with orography and local heating effects having a key role in determining local wind direction and strength. Sea and land temperature differences, which accumulate everyday throughout summer's major clear sky periods, create strong sea and land breezes. The wind regime of Cyprus is impacted by three key factors: (a) eastward moving cyclones, (b) huge temperature differences between the sea and the land, and (c) the mountain ranges, where local wind systems occur. However, despite the fact that high wind potential is not common in Cyprus, numerous sites have been found as having annual mean wind speeds more than 5 meters per second at 10 meters height. These areas include the island's southern coast as well as a few mountainous regions that are particularly exposed. These locations appear to be excellent candidates for the installation of wind turbines (Pashardes \& Christofides, 1995). The mean average speed is roughly $4 \mathrm{~m} / \mathrm{s}$, as illustrated (where). Recently, the EAC issued a large-scale tender for the establishment of Cyprus's first wind farm. An important part of the project is the construction of four 1.5-2 MW Wind Turbine Parks near the Kouris Dam in 
Limassol District. This Tender also involves the provision and installation of one 1.5-2 MW Wind Turbine at Vasilkos Power Station (Koroneos et al., 2005).

\section{Materials And Method}

The methods and input parameters utilized in this investigation are discussed in this section. The use of specific RES technologies depends on the country's renewable resource availability. Numerous hybrid configurations of these technologies were also examined, and lastly, the market economic results, renewable share, and $\mathrm{CO}_{2}$ emissions were analyzed.

The ENERGYPLAN simulation environment has been used to conduct the analysis for the different scenarios of renewable energy integration for meeting the energy demands. The analysis made involves both technical and economic simulations of the scenarios considered, whereby the ENERGYPLAN estimates the optimal system configuration utilizing the hourly computation within a specific time range. The ENERGYPLAN software functions by distributing critical excess electricity production (CEEP). The layout of the ENERGYPLAN software is shown in Fig. 5

The ENERGYPLAN architecture operates by input/output configurations, and have been used for national and regional energy systems. Furthermore, the computations performed within the ENERGYPLAN is by analytical programming, rather than iterations. Several studies have utilized the ENERGYPLAN software for optimal designs of combined heat and power systems, design of optimal transportation systems, feasibility of $100 \%$ renewable energy systems, and investigation of appropriate market for electricity in the fossil free energy systems (Liu, Lund, \& Mathiesen, 2011; H. Lund, 2006; H. Lund \& Andersen, 2005; Henrik Lund, 2005; Nielsen, Sorknæs, \& Østergaard, 2011). The ENERGYPLAN takes in some input parameters like energy demands, capacities of generation units, storage capacities, capacity factors of generation sources, transport sector, investment cost of different energy sources and generation units, maintenance costs, carbon dioxide emission factor of fuel. The retrieved result of the software include hourly electricity production, import/export electricity, import/export revenues, import/export expenditures, fuel consumption, and share of renewable energy sources. The model also allows incorporating mix of energy sources, of fossil fuel and renewable energy sources.

\section{Scenarios for Diversification of Cyprus electricity system}

The electricity demand in Cyprus is majorly met by thermal power which is run on imported oil supply. In Cyprus, there is $100 \%$ supply to meet electricity demand which have increased over the years. As at 1990 , the demand for electricity was 1.86 TWh. Between 1990 and 2020, the demand for electricity had risen by $60 \%$. This increase in electricity demand in Cyprus is attributed to rise in the population and the tourism activities on the Island. In this study, the ENERGYPLAN software is used in simulating future prospects of integrating renewable energy with present power plants. Also, $100 \%$ renewable energy is simulated, and these are done to assess the reduction of carbon dioxide. Also, the desalination process is simulated to be powered by electricity generated by the different scenarios of electricity production. Of worthy note, is that the choice of renewable energy sources simulated in this study is based on the renewable energy potential 
of Cyprus. A reference model reflecting the year 2020 was built to prove that the model accurately simulated the Irish energy sector. The inputs used and assumptions made to generate the reference model are reviewed in depth, with the conclusion that ENERGYPLAN provided an accurate simulation of the Irish energy system. Once the reference model was proven to be realistic, eight (8) different scenarios were developed and tested. These scenarios are developed based on future electricity consumption for the year 2050, which is estimated to be 8.3Twh/year. Annual Electricity demand including that for desalination is shown in Fig. 6. This estimation was made based the thorough study about the future energy consumption carried by Florides et al. (Florides, Kalogirou, Tassou, \& Wrobel, 2000) and Agathokleous et al. (Agathokleous, R. A., \& Kalogirou, 2020).

The eight scenario cases considered are described below. The optimization simulation flowchart and summary of the research model is shown in Figs. 7 and 8

\section{Case 1}

In the case 1 , the reference model using the $100 \%$ production from fossil fuel (oil) is used for electricity generation and desalination process.

The scenarios of integrating renewable energy sources into the electricity generation mix in Cyprus is also made. The case scenarios 2-4 gives a detailed analysis of this simulations. The modelling is carried out in such a way to avoid critical excess electricity production.

\section{Case 2}

The integration of photovoltaic system in the energy mix is simulated. The analysis is made to estimate the $\mathrm{CO}_{2}$ reduction and the cost effectiveness of the hybrid energy sources.

\section{Case 3}

The integration of onshore wind energy with the fossil fuel usage is simulated as a case scenario. In making this analysis, the capacity factor of the wind energy technologies, and relevant cost information are also inputted in the ENERGYPLAN software.

\section{Case 4}

The case of concentrated solar power (CSP) integration with fossil fuel usage is also modeled. The economic and technical analysis of this scenario is carried out.

The scenarios of integrating hybrid renewable energy sources are also considered. This involves combining the available solar and wind energy technologies with fossil fuel generation to meet the electricity and desalination demands. Case scenarios 5-7 gives the technical and economic details of the simulations.

\section{Case 5}


The case of integrating PV and wind energy technologies, with fossil fuel generation is simulated and the technical and economic analysis is carried out.

\section{Case 6}

The case scenario of integrating PV and CSP, with fossil fuel generation is simulated and the technical and economic analysis is carried out.

\section{Case 7}

The case scenario of integrating wind energy and CSP technologies, with fossil fuel generation is simulated. The results are used in explaining the feasibility in terms of technical, economic and environmental outputs.

The optimal projection is the case of having $100 \%$ energy generation from renewable sources.

\section{Case 8}

The scenario of having $100 \%$ renewable energy sources for electricity generation is considered in this case. In modelling this scenario, different combinations of renewable energy technologies are considered, as given below.

- Case a: PV/ Wind technologies

- Case b: PV/CSP/Storage technologies

- Case $\mathrm{c}$ : Wind/CSP/Storage technologies

- Case d: PV/Wind/CSP/Storage technologies

\section{Model Simulation Process and Economic Analysis}

For accurate modelling in the ENERGYPLAN software, the optimized result in terms of the technical feasibility of the different cases considered is made based on four different warnings which the software flashes. Based on these warnings, adjustments (based on trials) is made until an optimized result is retrieved. The first of these warnings is the Critical excess electricity production (CEEP) signal, which indicates that there is excess electricity after annual demands have been met. The model is adjusted by reducing the renewable energy productions until the CEEP signal is off. The second signal is the NO CEEP and Power plant Import (PPI) warning. This indicates that there is a balanced energy supply for meeting the demands. To guarantee optimal economic supply, power plant capacity is reduced slightly, with emphasis given to natural gas reduction. The third signal is the PPI warning. This indicates that there is inadequate energy supply to meet annual demands from the power plants. The model is adjusted by increasing the power plant capacity, with priority given to the renewable energy sources. The final signal is the CEEP and PPI warning, which indicates that there is excess electricity supply and unmet demands. The model is adjusted by decreasing and increasing the renewable energy supply and oil power plant production respectively. 
Furthermore, the economic analysis is made using the ENERGYPLAN database (ENERGYPLAN, 2018) which contains critical cost information like initial investment cost, operation and maintenance cost, interest rate, fuel cost, and variable and fixed costs. The interest rate used in this study is $0.1 \%$. The Economic parameters for RES and non-RES power production is shown in Table 3.

Table 3

Economic parameters for RES and non-RES power production (Lund H, Sorknæs P, Mathiesen BV, 2018)

\begin{tabular}{|llllll|}
\hline Technology & Unit & $\begin{array}{l}\text { Investment cost } \\
\text { (MEUR/unit) }\end{array}$ & $\begin{array}{l}\text { Fixed O\&M (\% of } \\
\text { investment) }\end{array}$ & $\begin{array}{l}\text { Lifetime } \\
\text { (years) }\end{array}$ & $\begin{array}{l}\text { Variable O \& M Cost } \\
\text { (EUR/MWh-e) }\end{array}$ \\
\hline Oil & MWe & 0.84 & 3.16 & 27 & 40 \\
\hline PV & MWe & 0.69 & 1.28 & 30 & \\
\hline Wind & MWe & 0.91 & 3.27 & 30 & 1.19 \\
\hline CSP & MWe & 3.8 & 4 & 50 & \\
\hline $\begin{array}{l}\text { Pump } \\
\text { storage }\end{array}$ & GWh & 7.50 & 1.5 & & \\
\hline
\end{tabular}

\section{Model Validation}

In order to ascertain the reliability of the model, validation is done using the electricity demand data between year 1990 and 2005, retrieved from the international energy agency (IEA) (IEA, n.d.). The ENERGYPLAN was used in modelling the energy demands, and the $\mathrm{CO}_{2}$ emission was compared with the actual $\mathrm{CO}_{2}$ data retrieved from the World Bank database (Bank, n.d.). Table 4 shows the deviation of the actual and modelled $\mathrm{CO}_{2}$ emissions. The deviation of $1.22 \%$ proves that the ENERGYPLAN can be trusted to give accurate estimations of the future energy situation in Cyprus.

Table 4

Validation of ENERGYPLAN model using $\mathrm{CO}_{2}$ results

\begin{tabular}{|c|c|c|c|c|}
\hline \multirow[t]{2}{*}{ Year } & \multirow[t]{2}{*}{ Actual demand (TWh) } & \multicolumn{2}{|c|}{$\mathrm{CO}_{2}$ emissions (Mt) } & \multirow[t]{2}{*}{$\%$ deviation } \\
\hline & & Actual & Model & \\
\hline 1990 & 1.86 & 5.948 & 5.767 & 3.13 \\
\hline 1995 & 2.38 & 6.781 & 6.700 & 1.20 \\
\hline 2000 & 3.18 & 7.495 & 7.456 & 0.52 \\
\hline 2005 & 4.21 & 7.658 & 7.655 & 0.039 \\
\hline Mean & 2.9075 & 6.9705 & 6.8945 & 1.22225 \\
\hline
\end{tabular}

\section{Results And Discussions}

The simulation results from the 8 case scenarios designed in this study to combat the dependence on oil for electricity generation in Cyprus are explained in this section. It has been stated that the results in this study 
will also be important for the energy decision making in the discourse of meeting the directive by the European Union for increasing renewable energy production in European states. The analysis made in this study are for hourly time-steps for a year. The results presented include the generation capacity of different technologies, total investment, carbon emission expelled, renewable energy share in power and electricity produced, and renewable energy sources for electricity production. In computing the variable cost, the marginal cost, fuel cost, and $\mathrm{CO}_{2}$ emission cost are considered. The annual variable cost, fixed cost, and investments are summed to yield the total annual cost.

In discussing the most feasible solutions for different technologies, the factors that will be considered include maximum renewable energy integration, economic feasibility, systems without CEEP, and least carbon emissions. Furthermore, the most feasible combination of renewable energy technologies for $100 \%$ renewable electrification is also discussed. Finally, discussion is made regarding the policies that can be adopted to ensure optimal renewable energy integration in Cyprus.

The Fig. 6 shows the typical electricity demand profile in Cyprus for 2050. It can deduced, from the result presented, that the maximum electricity load is $825 \mathrm{MW}$ while the minimum system load is $268 \mathrm{MW}$. The winter season in Cyprus does not get to extreme levels of negative temperature, therefore the electricity needs for cooling is the cause for peak electricity demands in the summer seasons as seen in the Fig. 9.

In the case scenario one (reference case) for $100 \%$ access to electricity oil power plants, which will also be used for electricity generation and supply to end users including desalination, is modelled. In this simulation, the 2050 projected demand of 8.3 TWh can be met by the available thermal power plant with a capacity of $1478 \mathrm{MW}$, with primary energy supply of $18.55 \mathrm{TWh}$ /year. The peak demand is $1254 \mathrm{MW}$, the carbon emission produced will be $4.9 \mathrm{Mt}$ yearly and there is no CEEP in the primary energy supply. The annual cost for this proposed installation is $\$ 302$ million, which comprises of variable cost of $\$ 223$ million, fixed operation cost of $\$ 33$ million, and annual investment cost of $\$ 45$ million. The annual $\mathrm{CO}_{2}$ emission cost was computed to be $\$ 49$ million.

The integration of renewable energy sources (RES) into the electricity production in Cyprus will be gradual, especially considering that electricity is presently (in 2021) being produced almost solely by fossil fuel. Furthermore, the intermittence of RES would necessitate their combination with fossil fuel power plants (especially when cost of storage is to be avoided). The feasibility of having $100 \%$ renewable energy electricity is argued in the energy market. Except from photovoltaic (PV) systems, whose technology have been growing over the years (Wang et al., 2021), most other RES are less cost effective than fossil fuels. Six (6) different combinations of RE and non-RE technologies have been simulated on the ENERGYPLAN.

The second scenario is the integration of PV with fossil fuel (Oil) for electricity generation. The results from the optimization process reveal that an installed capacity of $1300 \mathrm{MW}$ and $1000 \mathrm{MW}$ of fossil fuel power plant (PP) and PV respectively will be sufficient for meeting the electricity demands without CEEP. The PV installations would supply $1.68 \mathrm{TWh}$ /year which represents $20.1 \%$ renewable energy share of electricity production. The oil power plant installations would supply $6.67 \mathrm{TWh} / \mathrm{year}$. The $\mathrm{CO}_{2}$ emission cost in this case decreases by $20.4 \%$ as against when only fossil fuel is used in meeting the electricity demands. The 
total investment cost for the oil PP/PV is calculated to be 1782 million EUROS. Figure 10 shows that annual electricity demand and supply from PV and Oil power plants

The performance of concentrated solar power (CSP) and fossil fuel PP for electricity production is simulated as the third scenario. This scenario is without any storage for the CSP system. This is done so as to compare it with a scenario having 100\% storage. Based on the constraints considered, the optimum installation is estimated as 1300MW and 1000MW of fossil fuel PP and CSP respectively. The electricity production from the CSP system is 1.9TW/year, while the electricity production from fossil fuel power plant is estimated to be $6.45 \mathrm{TW} /$ year. The renewable energy share in electricity production for this scenario is calculated to be $22.8 \%$, as compared to $11.7 \%$ share in the primary energy supply. The total investment cost for the combined CSP and oi PP is calculated to be 4982 million EUROS. The $\mathrm{CO}_{2}$ emission was reduced as a result of integration CSP into the fossil fuel electricity grid, by $22.7 \%$ to $3.818 \mathrm{Mt}$. Figure 11 shows that annual electricity demand and supply from CSP and Oil PP.

The Case scenario four (4) is the proposed oil PP and wind energy for electricity production in Cyprus. In meeting the electricity demands without CEEP, the optimized Wind energy capacity and Oil PP estimated was $940 \mathrm{MW}$ and $1215 \mathrm{MW}$ respectively. The electricity production from the wind technology is estimated to be 1.55 TWh/year, which represents $18.5 \%$ share of electricity. The Oil PP will produce and additional 6.8 TWh/year. This proposed case scenario is estimated to cut $\mathrm{CO}_{2}$ emission by $18.5 \%$ to $4.941 \mathrm{Mt}$. The total investment cost calculated for the total system is 1876 million EUROS. FIgure 12 shows the hourly electricity demand and supply from the wind and Oil power plants.

Using hybrid renewable energy technologies to generate power increases energy security and diversity, and will optimize the renewable potential in a country. In the case scenario five (5), PV and wind energy combined with the Oil power plants for meeting electricity demands in Cyprus is modelled. The combined renewable energy share for electricity production was calculated to be $24.6 \%$, for which 2.05 TWh/year of electricity was produced. Considering that the constraint of NO CEEP was met, the Oil PP augmented 6.3TWh/year. It is of worthy note that the wind technology produced 1.19TWh/year while the PV plant produced 0.86TWh/year, and this variability is attributed to the intermittence of both renewable resources. The annual $\mathrm{CO}_{2}$ emission from this proposed installation was 3.729Mt which represented a reduction of 24.5\%. The economic analysis showed that the Oil PP, wind technology, and PV plant had an investment cost of 1000 million EUROS, 660 million EUROS, and 352 million EUROS respectively. Figure 13 shows that annual electricity demand and supply from PV, Wind and Oil PP.

In the case scenario six (6), PV and CSP, combined with the Oil PP is modelled. The combined renewable energy share for electricity production was calculated to be $21.5 \%$, for which $1.79 \mathrm{TWh}$ /year of electricity was produced. The Oil PP augmented 6.56TWh/year. The annual $\mathrm{CO}_{2}$ emission from this proposed installation was 3.882Mt which represented a reduction of $21.4 \%$. The economic analysis showed that the Oil PP, CSP technology, and PV plant had an investment cost of 1092 million EUROS, 1900 million EUROS, and 345 million EUROS respectively. Figure 14 shows that annual electricity demand and supply from CSP, PV and Oil PP. 
In the case scenario seven (7), Wind and CSP combined with the Oil PP was modelled to analyze the technical and economic viability of the installation. The combined renewable energy share for electricity production was calculated to be $26 \%$, for which 2.17 TWh/year of electricity was produced. The Oil PP augmented 6.18TWh/year. The individual renewable energy technologies generated: wind energy was $1.22 \mathrm{TWh} /$ year, CSP generated $0.95 \mathrm{TWh} /$ year. The annual $\mathrm{CO}_{2}$ emission from this proposed installation was $3.659 \mathrm{Mt}$ which represented a reduction of $25.94 \%$. The economic analysis showed that the Oil PP, CSP technology, and Wind plant had a total investment cost of 1000 million EUROS, 1900 million EUROS, and 673 million EUROS respectively. Figure 15 shows that annual electricity demand and supply from CSP, Wind and Oil power plants.

The ideal situation is to fully maximize the renewable energy resource in Cyprus. Case scenarios of $100 \%$ renewable energy using different combinations of PV, CSP, and wind energy with storage possibilities is simulated. The scenario 8 is subdivided into combinations of PV/Wind/Storage, CSP/Wind/Storage, and $\mathrm{PV} / \mathrm{CSP} / \mathrm{Wind} /$ storage renewable energy technologies for meeting the 8.3TWh/year of electricity demand (also used for desalination process). The most feasible option for $100 \%$ RE generation in Cyprus for the year 2050 is analyzed based on the simulation results. This is so because the electricity produced using the different RES have little difference. The minimum storage for the RE technologies was $30 \mathrm{GW}$. It is of noteworthy that increasing the storage size will decrease the CEEP, as all the renewable energy technologies have CEEP. The total investment cost for the PV/Wind/Storage, CSP/Wind/Storage, and PV/Wind/CSP/storage was 9810 million EUROS, 21,415 million EUROS, and 15,851 million EUROS.

Figure 16 shows the hourly electricity profile for the $100 \%$ renewable energy technologies with $30 \mathrm{GW}$ storage. The most feasible proposed electricity generation using Renewable energy was PV/Wind/30GW Storage. The renewable energy electricity generated was 19.04TWh/year, which shows that there is CEEP in the system, for which increase in the storage can tackle. Figures 17 and 18 shows the annual electricity balance showing CEEP (PV/Wind/Storage) and export electricity respectively.

Summarily, in comparative discourse of the different scenarios considered in this study, which was chosen based on the available energy resources in the country (Cyprus), certain inferences can be drawn. The Fig. 19 which shows that based on the $\mathrm{CO}_{2}$ reduction as against the reference scenario, the Oil PP/Wind/CSP technologies and Oil/PV/Wind, gave the most feasible scenario. The total annual costs (which comprise of variable and fixed cost) of the scenarios is presented in the Fig. 20. The least annual cost is calculated for Oil PP/PV technologies, with a total annual cost of 142 million EUROS. It is noteworthy that all the proposed scenarios of integrating renewable energy with the Oil PPs have lesser annual costs (except for the Oil PP/CSP). This shows that integrating renewable energy into the electricity grid in Cyprus is economically feasible.

\section{Challenges to RE integration and Policy Prospects of Renewable energy integration in Cyprus}

There are some characteristics of the Cyprus case that make it particularly intriguing. Because there are currently no connections between the electrical grids of neighboring nations and therefor island's electricity distribution infrastructure, it is fully isolated (a grid interconnection, the EuroAsia Interconnector, between Israel, Cyprus and Greece is currently under investigation ( $\mathrm{r}$ o j e c ts o f c o mmo $\mathrm{n}$ in te r e s t - E I e c tr i c $\mathrm{i}$ 
ty a $\mathrm{n} \mathrm{d} \mathrm{S} \mathrm{ma} \mathrm{rt} \mathrm{G} \mathrm{ri} \mathrm{d} \mathrm{s,} \mathrm{2014).} \mathrm{As} \mathrm{a} \mathrm{result,} \mathrm{Cyprus} \mathrm{must} \mathrm{always} \mathrm{meet} \mathrm{its} \mathrm{electricity} \mathrm{demand} \mathrm{using} \mathrm{domestic}$ generation resources and confronts additional hurdles when it comes to incorporating a substantial percentage of variable renewable energy technologies into the power grid due to the system's inherent inflexibility. The recent discovery of offshore natural gas can be a distraction towards RE integration to the electricity grid in Cyprus. The government of Cyprus has been discussing the possibility of exporting this natural gas reserves to offset the imbalance of energy and reducing the cost of electricity generation (Taliotis et al., 2017). Despite this, the future prospect of renewables in Cyprus can be viewed with hope. This stems from the success of the saturation of domestic application of solar technology for heating and cooling. This goes to show that solar technology for energy production is a great interest in Cyprus (Maxoulis, Charalampous, \& Kalogirou, 2007). Further penetration of solar technologies for electricity generation would be enhanced by favorable renewable policies. From the Action Plan for Renewable Energy Sources in Cyprus (APRES) project (formulated in 2002), Cyprus had a renewable energy electricity integration target of $6 \%$, which was projected to be increased to $12 \%$. This RE integration projection was backed up by some plans

- Utilizing of 0.0013Euros/KWh from electricity bill as RE funds

- Purchase of green KWh of electricity by the Electricity Authority of Cyprus (EAC) for 0.037Euros

- Subsidized PV system of 5kW, and purchase of PV electricity for $0.12 E u r o s / K W h$ by the EAC

The APRES scheme which ended in 2006, was improved in 2007, with same amount of subsidies, however the size of system was increased to $25 \mathrm{KW}$. Also, in the new scheme of 2007, the rate of purchase of electricity was increased to 0.224 Euros/KWh for private individuals and 0.196 Euros/KWh for industries.

Based on the simulation calculated in this study, the most feasible option for RE integration to the electricity grid, is utilizing PV and Wind technologies. In the 2006 APRES scheme, the major attention was on installing wind generating systems, for which a total capacity of $265.6 \mathrm{MW}$ was licensed. Future policy considerations should consider utilization of the rich solar resource in the region. The model showed that the PV/Wind/Oil PP and $100 \%$ RET of PV/Wind/Storage would yield optimized technical and economic outputs.

The implementation of smart grid and energy management systems in the country would result in the introduction of new and more sophisticated technology that would improve energy services while simultaneously reducing waste. Smart infrastructure and equipment, smart buildings and construction, smart transportation networks, and ICT-enabled carbon/energy management and reporting are all examples of ICT-based innovations that can result in significant energy savings (Alharbi \& Csala, 2021).

\section{Conclusion}

This study explored the electricity situation in Cyprus. Considering that Cyprus represents a unique situation of both $100 \%$ electricity access and independent grid system, the integration of Renewable energy sources for meeting the RE targets of the European Union represents a situation worth investigating. Cyprus is heavily dependent on importation of Oil for electricity generation. This study therefore considers the integration of renewable energy technologies (Solar, Wind, and CSP) with the Oil power plants to meet the 
projected electricity demand for 2050 . Also, this study goes further to model a $100 \%$ renewable energy electricity generation using different combination of dual and ternary configurations of varying renewable energy sources. The ENERGYPLAN software was the simulation environment used in assessing the technical, economic, and environment feasibility of the different scenarios developed in this study. The analysis which considered hourly electricity demand and supply on an annual bases, retrieved some significant results, as follows:

- The optimum scenario for electricity generation for 2050 was PV system integrated with the Oil Power plants. The PV part of this system would generate 1.68TWh/year of renewable energy electricity.

- The highest $\mathrm{CO}_{2}$ emission reduction as against the reference $\mathrm{CO}_{2}$ emission of $4.941 \mathrm{Mt}$ was $26 \%$, from the Oil PP/Wind/CSP technology.

- For $100 \%$ renewable energy electricity generation, the most feasible option was the PV/Wind/30GW storage system. This system would have an installation of 4000MW PV capacity, and 7500MW wind capacity.

- It is noteworthy that all the proposed scenarios of integrating renewable energy with the Oil power plants (except for the Oil PP/CSP) have lesser annual costs. This shows that integrating renewable energy into the electricity grid in Cyprus is economically feasible.

- The total investment cost for the PV/Wind/Storage, CSP/Wind/Storage, and PV/Wind/CSP/storage is 9,810 million EUROS, 21,415 million EUROS, and 15,851 million EUROS

- The least annual cost is calculated for Oil PP/PV technologies, with a total annual cost of 142 million EUROS

- Despite that the potential for $100 \%$ renewable energy integration is possible, it is recommended, based upon the complexity of the electricity grid in Cyprus that concentration should be to integrate PV and Wind energy steadily into the grid system.

- In the 2006 APRES scheme, the major attention was on installing wind generating systems, for which a total capacity of $265.6 \mathrm{MW}$ was licensed. Future policy considerations should consider utilization of the rich solar resource in the region. The model showed that the PV/Wind/Oil PP and 100\% RET of $\mathrm{PV} /$ Wind/Storage would yield optimized technical and economic outputs.

\section{Declarations}

The authors declare that there is no conflict of interest

\section{References}

1. (EAC), E. A. of C. (2021). Power station capacity. Retrieved from https://www.eac.com.cy/EN/RegulatedActivities/Generation/powerstationcapacity/Pages/default.aspx

2. Agathokleous, R. A., \& Kalogirou, S. A. (2020). Target for $100 \%$ Renewable Energy Systems Use in Cyprus for Electricity Production. In Solar Energy Conversion in Communities, 179-194. 
3. Alexopoulos, S., \& Hoffschmidt, B. (2010). Solar tower power plant in Germany and future perspectives of the development of the technology in Greece and Cyprus. Renewable Energy, 35(7), 1352-1356. https://doi.org/10.1016/j.renene.2009.11.003

4. Alharbi, F. R., \& Csala, D. (2021). Gulf cooperation council countries' climate change mitigation challenges and exploration of solar and wind energy resource potential. Applied Sciences (Switzerland), 11(6). https://doi.org/10.3390/app11062648

5. Bank, W. (n.d.). CO2 Emissions data. Retrieved from https://data.worldbank.org/indicator/EN.ATM.CO2E.PC?locations=CY

6. Climate, W. and. (n.d.). weather-and-climate.com/average-monthly-hours-Sunshine,Nicosia,Cyprus. Retrieved from https://weather-and-climate.com/average-monthly-hours-Sunshine,Nicosia,Cyprus

7. Connolly, D., Lund, H., Mathiesen, B. V., \& Leahy, M. (2011). The first step towards a $100 \%$ renewable energy-system for Ireland. Applied Energy, 88(2), 502-507. https://doi.org/10.1016/j.apenergy.2010.03.006

8. Ćosić, B., Krajačić, G., \& Duić, N. (2012). A 100\% renewable energy system in the year 2050: The case of Macedonia. Energy, 48(1), 80-87. https://doi.org/10.1016/j.energy.2012.06.078

9. Cyprus Department of Environment Seventh national communication \& third biennial report. (2018). Retrieved from https://unfccc.int/documents/64731

10. D., C. (2018). EnergyPLAN cost database:

11. del Río, P. (2017). Why does the combination of the European Union Emissions Trading Scheme and a renewable energy target makes economic sense? Renewable and Sustainable Energy Reviews, 74(January), 824-834. https://doi.org/10.1016/j.rser.2017.01.122

12. Demetriou, E., Mallouppas, G., \& Hadjistassou, C. (2021). Embracing carbon neutral electricity and transportation sectors in Cyprus. Energy, 229, 120625. https://doi.org/10.1016/j.energy.2021.120625

13. (n.d.). Renewable energy. Retrieved from ec.europa.eu/energy/en/topics/renewable-energy.

14. Energy for the future: renewable sources of energy. White paper for a community strategy and action plan;COM (97) 599. (n.d.).

15. ENERGYPLAN. (2018). Sustainable Energy Planning Research Group. EnergyPLAN cost database.

16. Eurostat, S. E. (2015). Waste_statistics_-_electrical_and_electronic_equipment.

17. Fernandes, L., \& Ferreira, P. (2014). Renewable energy scenarios in the Portuguese electricity system. Energy, 69, 51-57. https://doi.org/10.1016/j.energy.2014.02.098

18. Fernández, R. A. (2021). Stochastic analysis of future scenarios for battery electric vehicle deployment and the upgrade of the electricity generation system in Spain. Journal of Cleaner Production, 316(January). https://doi.org/10.1016/j.jclepro.2021.128101

19. Florides, G. A., Kalogirou, S. A., Tassou, S. A., \& Wrobel, L. C. (2000). Modeling of the modern houses of Cyprus and energy consumption analysis. Energy, 25(10), 915-937. https://doi.org/10.1016/S03605442(00)00030-X

20. Harmelink, M., Voogt, M., \& Cremer, C. (2006). Analysing the effectiveness of renewable energy supporting policies in the European Union. Energy Policy, 34(3), 343-351. 
https://doi.org/10.1016/j.enpol.2004.08.031

21. Hartmann, N., \& Özdemir, E. D. (2011). Impact of different utilization scenarios of electric vehicles on the German grid in 2030. Journal of Power Sources, 196(4), 2311-2318. https://doi.org/10.1016/j.jpowsour.2010.09.117

22. IEA. (n.d.). Cyprus. Retrieved from https://www.iea.org/countries/cyprus

23. IEA. (2021a). Energy consumption, Cyprus. Retrieved from https://www.iea.org/countries/cyprus

24. IEA. (2021b). key-world-energy-statistics-2021/supply. Retrieved from https://www.iea.org/reports/keyworld-energy-statistics-2021/supply

25. IEA (International Energy Agency). (2012). World Energy Outlook. Paris, France.

26. International Trade Association. (n.d.). Cyprus - Country Commercial Guide. Retrieved from https://www.trade.gov/country-commercial-guides/cyprus-renewable-energy-sources-res

27. Jochem, P., Babrowski, S., \& Fichtner, W. (2015). Assessing CO2 emissions of electric vehicles in Germany in 2030. Transportation Research Part A: Policy and Practice, 78(2015), 68-83. https://doi.org/10.1016/j.tra.2015.05.007

28. Kahia, M., Aïssa, M. S. Ben, \& Lanouar, C. (2017). Renewable and non-renewable energy use - economic growth nexus: The case of MENA Net Oil Importing Countries. Renewable and Sustainable Energy Reviews, 71(December 2016), 127-140. https://doi.org/10.1016/j.rser.2017.01.010

29. Khaligh, A., \& Li, Z. (2010). Battery, ultracapacitor, fuel cell, and hybrid energy storage systems for electric, hybrid electric, fuel cell, and plug-in hybrid electric vehicles: State of the art. IEEE Transactions on Vehicular Technology, 59(6), 2806-2814. https://doi.org/10.1109/TVT.2010.2047877

30. Koroneos, C., Fokaidis, P., \& Moussiopoulos, N. (2005). Cyprus energy system and the use of renewable energy sources. Energy, 30(10), 1889-1901. https://doi.org/10.1016/j.energy.2004.11.011

31. Liu, W., Lund, H., \& Mathiesen, B. V. (2011). Large-scale integration of wind power into the existing Chinese energy system. Energy, 36(8), 4753-4760. https://doi.org/10.1016/j.energy.2011.05.007

32. Lund H, Sorknæs P, Mathiesen BV, H. K. (2018). Beyond sensitivity analysis: a methodology to handle fuel and electricity prices when designing energy scenarios. Energy Res. Soc. Sci.

33. Lund, H. (2006). Large-scale integration of optimal combinations of PV, wind and wave power into the electricity supply. Renewable Energy, 31(4), 503-515. https://doi.org/10.1016/j.renene.2005.04.008

34. Lund, H., \& Andersen, A. N. (2005). Optimal designs of small CHP plants in a market with fluctuating electricity prices. Energy Conversion and Management, 46(6), 893-904. https://doi.org/10.1016/j.enconman.2004.06.007

35. Lund, Henrik. (2005). Large-scale integration of wind power into different energy systems. Energy, 30(13), 2402-2412. https://doi.org/10.1016/j.energy.2004.11.001

36. Mathiesen SR, Vad Brian, Lund Henrik, Hansen Kenneth, Ridjan Iva, Djørup R, Nielsen Steffen, Sorknæs Peter, Thellufsen Jakob Zinck, Grundahl Lars, Lund, Søgaard PA, Drysdale Dave, Connolly David, $\varnothing$. (2015). IDA's. Energy vision 2050 A smart energy system strategy for $100 \%$ renewable Denmark. Dep. Dev. Planning. Aalborg Univ. 
37. Maxoulis, C. N., Charalampous, H. P., \& Kalogirou, S. A. (2007). Cyprus solar water heating cluster: A missed opportunity? Energy Policy, 35(6), 3302-3315. https://doi.org/10.1016/j.enpol.2006.11.021

38. Mesimeris, T., Kythreotou, N., Partasides, G., \& Piripitsi, K. (2019). Cyprus' draft integrated national energy and climate plan for the period 2021-2030. Republic of Cyprus, (January 2019). Retrieved from https://ec.europa.eu/energy/sites/ener/files/documents/cyprus_draftnecp.pdf

39. Michaelides, J. M., \& Votsis, P. P. (1991). Energy analysis and solar energy development in Cyprus. Computing \& Control Engineering Journal, 2(5), 211-215.

40. Nielsen, S., Sorknæs, P., \& Østergaard, P. A. (2011). Electricity market auction settings in a future Danish electricity system with a high penetration of renewable energy sources - A comparison of marginal pricing and pay-as-bid. Energy, 36(7), 4434-4444. https://doi.org/10.1016/j.energy.2011.03.079

41. OECD/ILO. (2019). Policy Brief Policy Brief. Pancanaka, 1(101), 14.

42. Otter, C. (2018). The Circular Economy - An Explainer. (10), 1-32. Retrieved from https://www.parliament.vic.gov.au/publications/research-papers/download/36-research-papers/13880the-circular-economy-an-explainer

43. Pashardes, S., \& Christofides, C. (1995). Statistical analysis of wind speed and direction in Cyprus. Solar Energy, 55(5), 405-414. https://doi.org/10.1016/0038-092X(95)00064-X

44. Plötz, P., Schneider, U., Globisch, J., \& Dütschke, E. (2014). Who will buy electric vehicles? Identifying early adopters in Germany. Transportation Research Part A: Policy and Practice, 67, 96-109. https://doi.org/10.1016/j.tra.2014.06.006

45. Porubova, J., \& Bazbauers, G. (2010). Analysis of Long-Term Plan for Energy Supply System for Latvia that is $100 \%$ Based on the Use of Local Energy Resources. Environmental and Climate Technologies, 4(1), 82-90. https://doi.org/10.2478/v10145-010-0022-7

46. Profile, C. (n.d.). A Greener Future. Retrieved from https://www.cyprusprofile.com/sectors/energyrenewables

47. Profile, E. (2008). Energy Profile. The IUPAC Compendium of Chemical Terminology. https://doi.org/10.1351/goldbook.e02112

48. rojects of co mmo n in terest-El e ctricity a nd S mart G rids. (2014). 720.

49. Serghides, D. K., Dimitriou, S., \& Katafygiotou, M. C. (2016). Towards European targets by monitoring the energy profile of the Cyprus housing stock. Energy and Buildings, 132(2016), 130-140. https://doi.org/10.1016/j.enbuild.2016.06.096

50. Spencer, T., Colombier, M., \& Ribera, T. (2013). Policy brief The 2030 EU Climate and Energy Package: why and how? (December 2013).

51. Taliotis, C., Taibi, E., Howells, M., Rogner, H., Bazilian, M., \& Welsch, M. (2017). Renewable energy technology integration for the island of Cyprus: A cost-optimization approach. Energy, 137(2017), 3141. https://doi.org/10.1016/j.energy.2017.07.015

52. Van Wees, M. T., Uyterlinde, M. A., \& Maly, M. (2002). Energy efficiency and renewable energy policy in the Czech Republic within the framework of accession to the European Union. Energy, 27(11), 10571067. https://doi.org/10.1016/S0360-5442(02)00068-3 
53. Wang, Q., Li, M., Peng, Z., Kirby, N., Deng, Y., Ye, L., \& Geng, Y. (2021). Calculation aided miscibility manipulation enables highly efficient polythiophene:nonfullerene photovoltaic cells. Science China Chemistry, 64(3), 478-487. https://doi.org/10.1007/s11426-020-9890-6

54. Xu, L., Yilmaz, H. Ü., Wang, Z., Poganietz, W. R., \& Jochem, P. (2020). Greenhouse gas emissions of electric vehicles in Europe considering different charging strategies. Transportation Research Part $D$ : Transport and Environment, 87(September), 102534. https://doi.org/10.1016/j.trd.2020.102534

\section{Figures}

\section{Total Energy Supply, 2019}

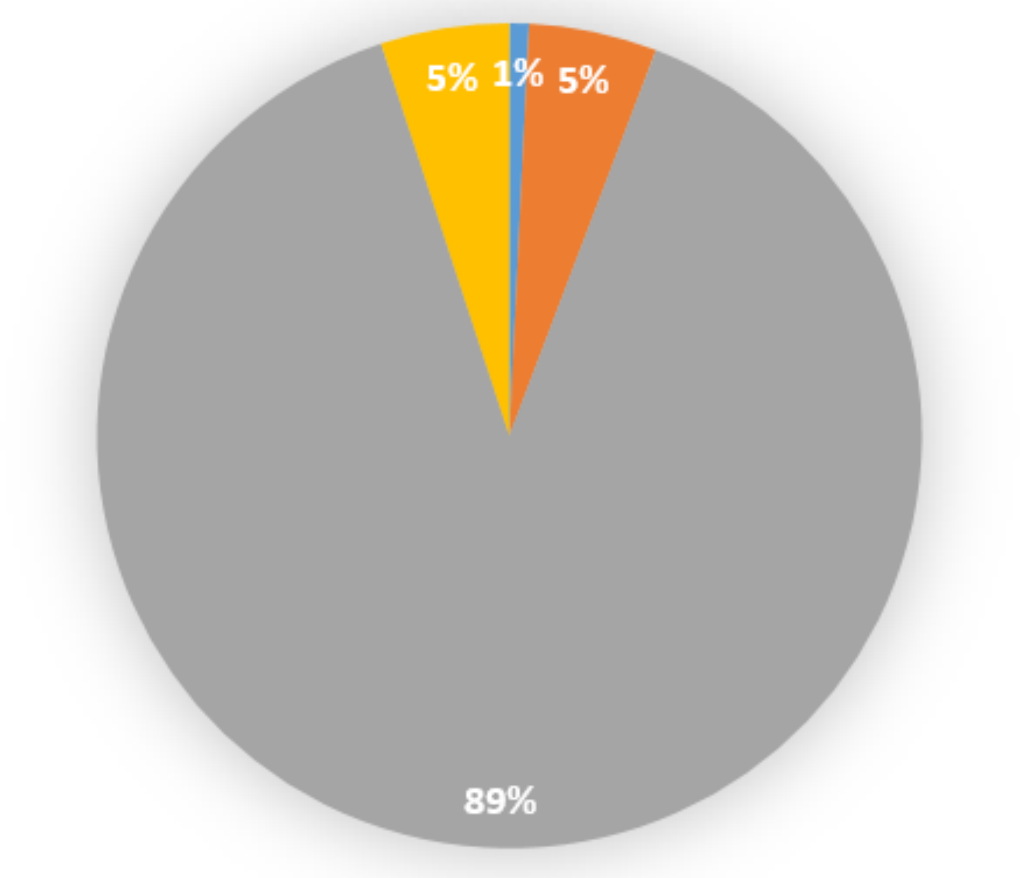

@ Coal $\square$ Biofuels and waste $\quad$ @ Oil $\square$ Wind, solar, etc.

\section{Figure 1}

Total energy supply for Cyprus (IEA, 2021b) 


\section{Electricity Consumption, Cyprus}

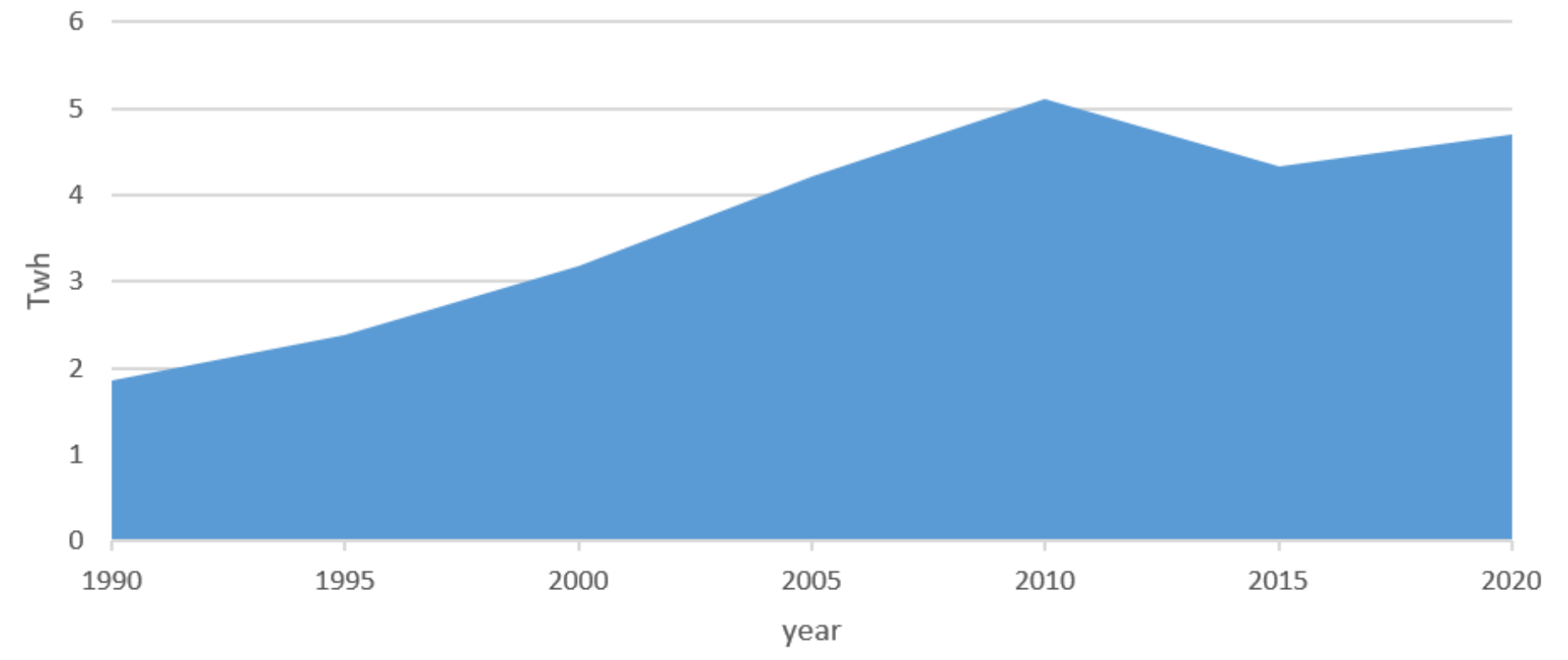

Figure 2

Electricity consumption in Cyprus (IEA, 2021a)

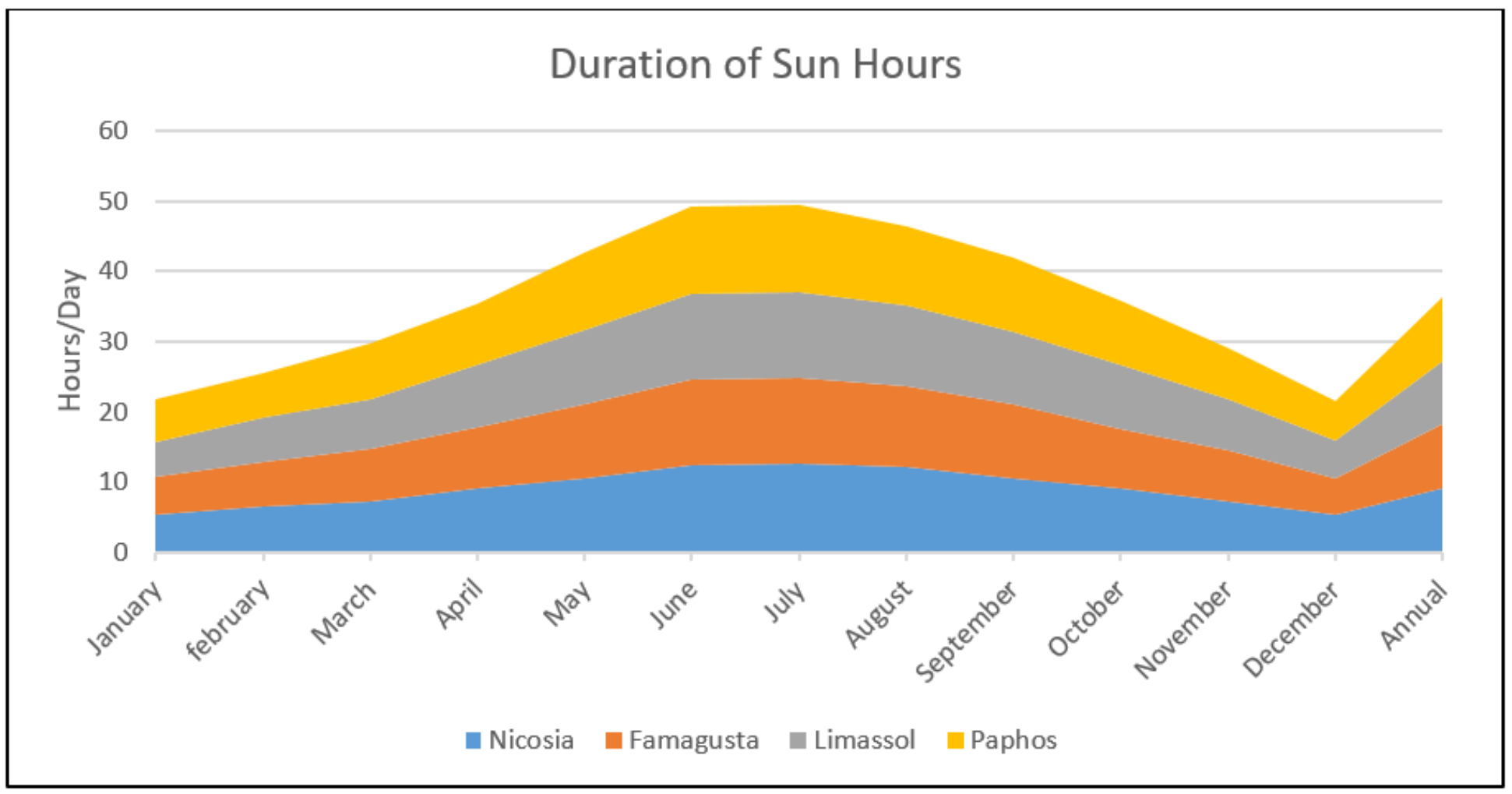

Figure 3

Sunshine duration in Cyprus cities (Climate, n.d.) 


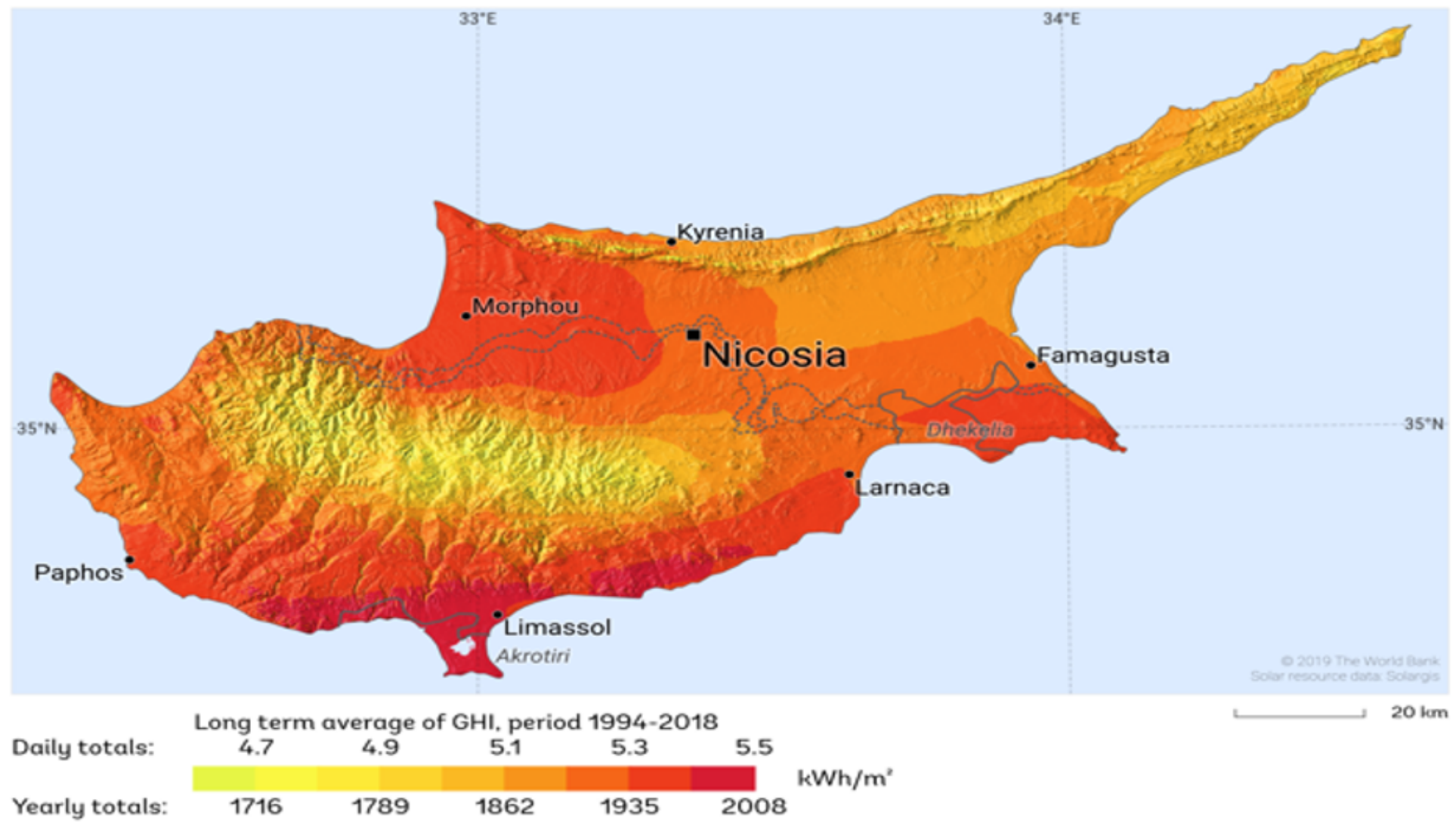

Figure 4

Global horizontal irradiation in Cyprus (Climate, n.d.) 


\section{Figure 5}

Layout of ENERGYPLAN simulator

\section{Figure 6}

Hourly Electricity demand (Current, 2021) 


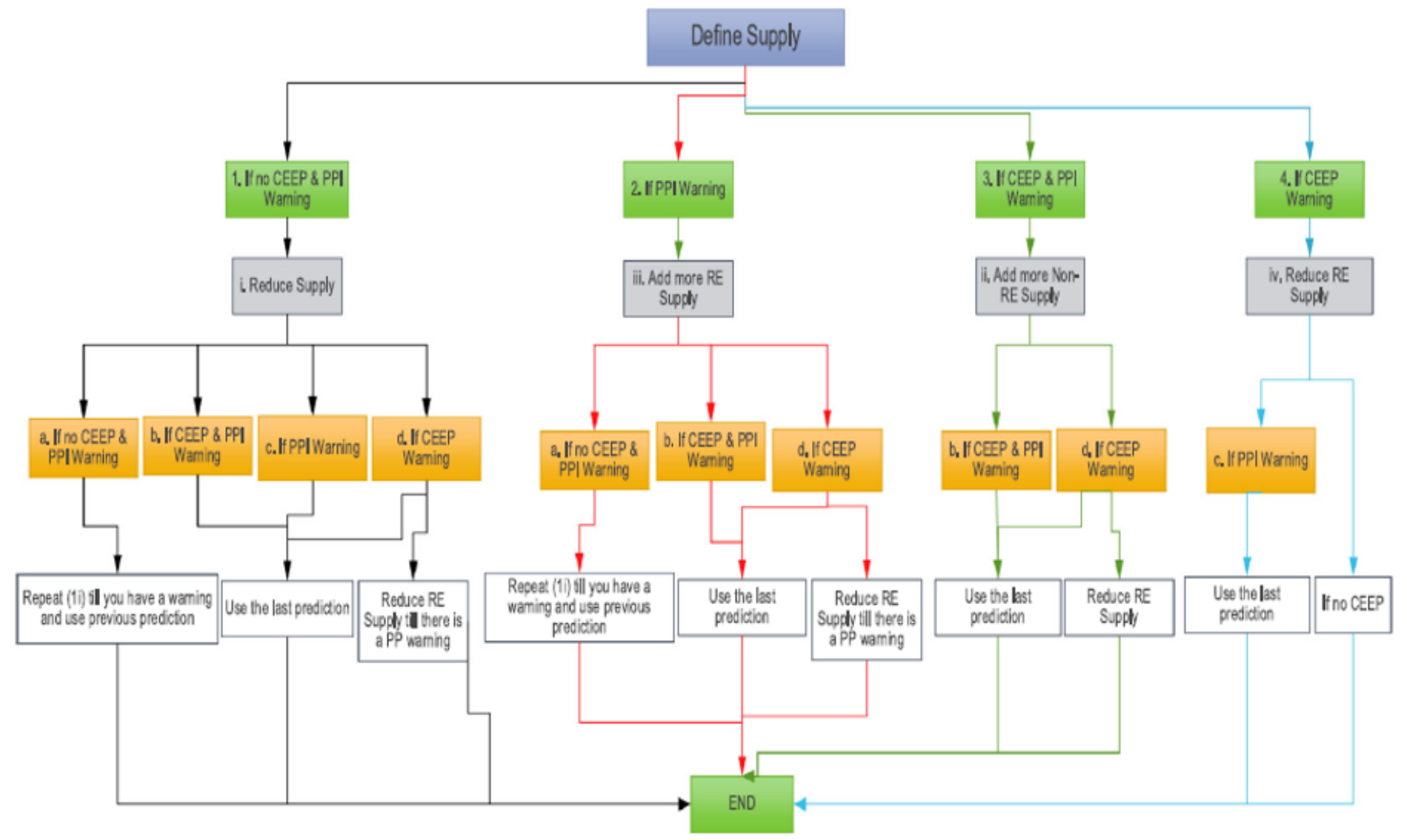

Figure 7

Optimization simulation flowchart

Figure 8

Summary of the research model 


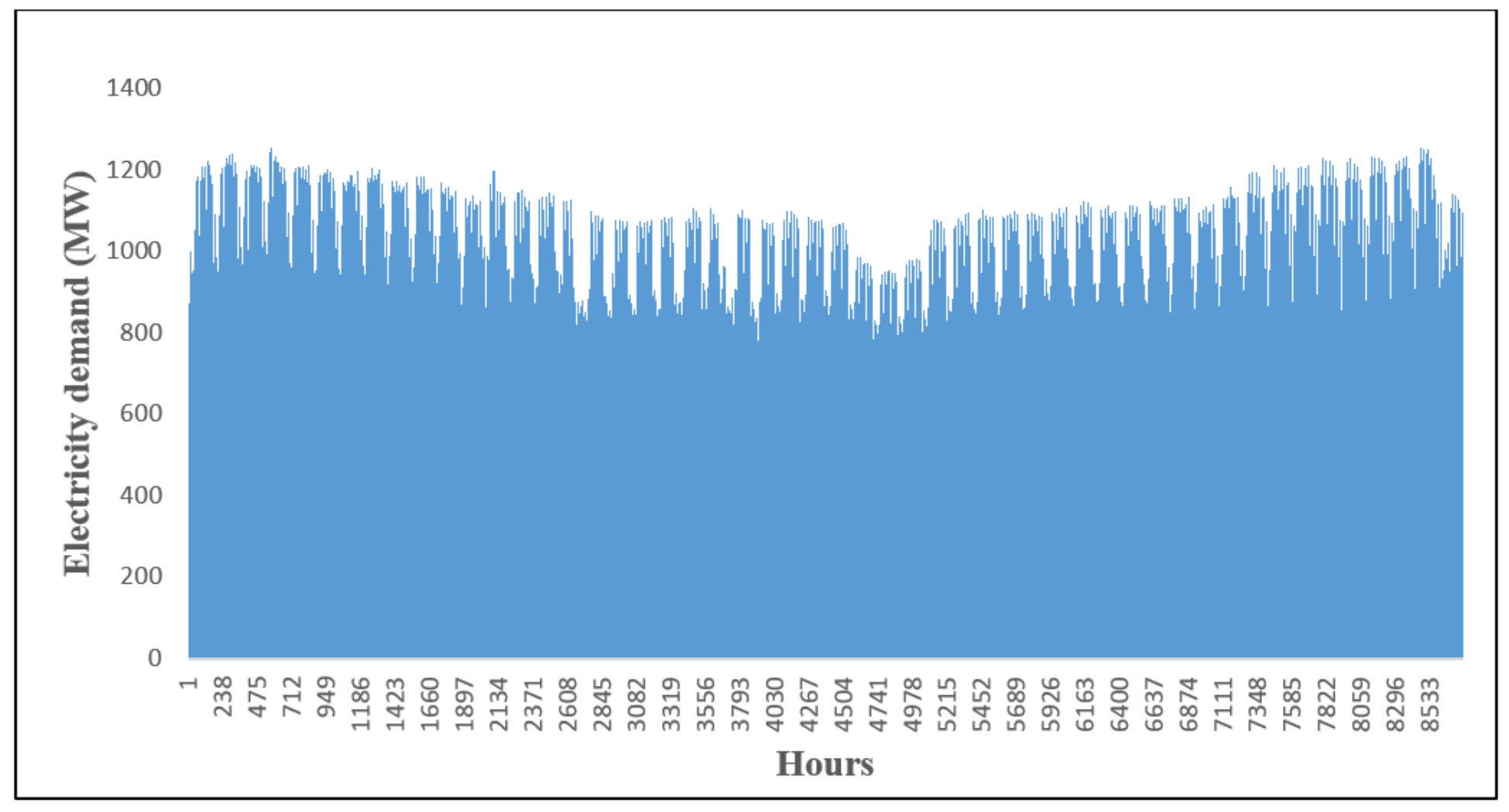

Figure 9

Electricity demand for 2050 in Cyprus

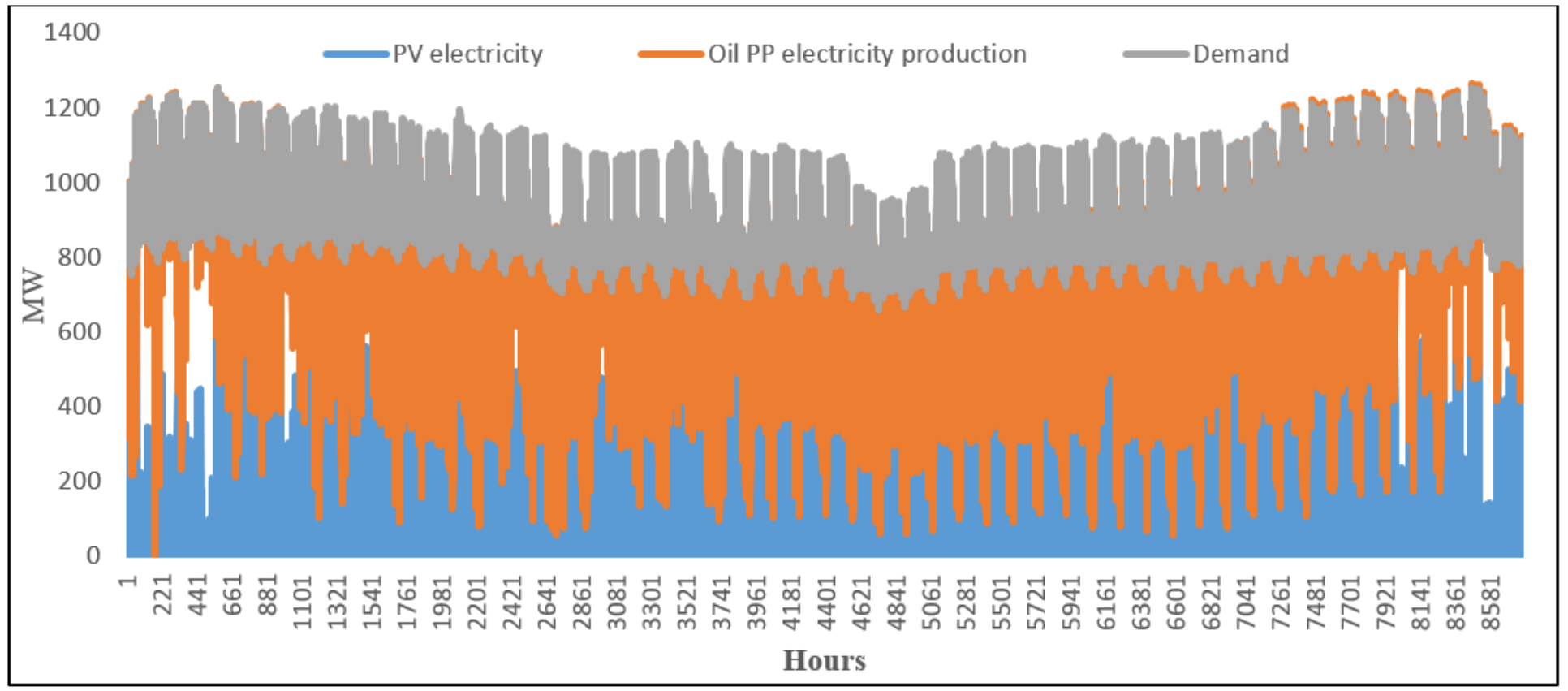

Figure 10

Annual electricity demand and supply from PV and Oil power plants 
Figure 11

Annual electricity demand and supply from CSP and Oil power plants

Figure 12

Annual electricity demand and supply from Wind and Oil power plants

\section{Figure 13}

Annual electricity demand and supply from PV, Wind and Oil power plants

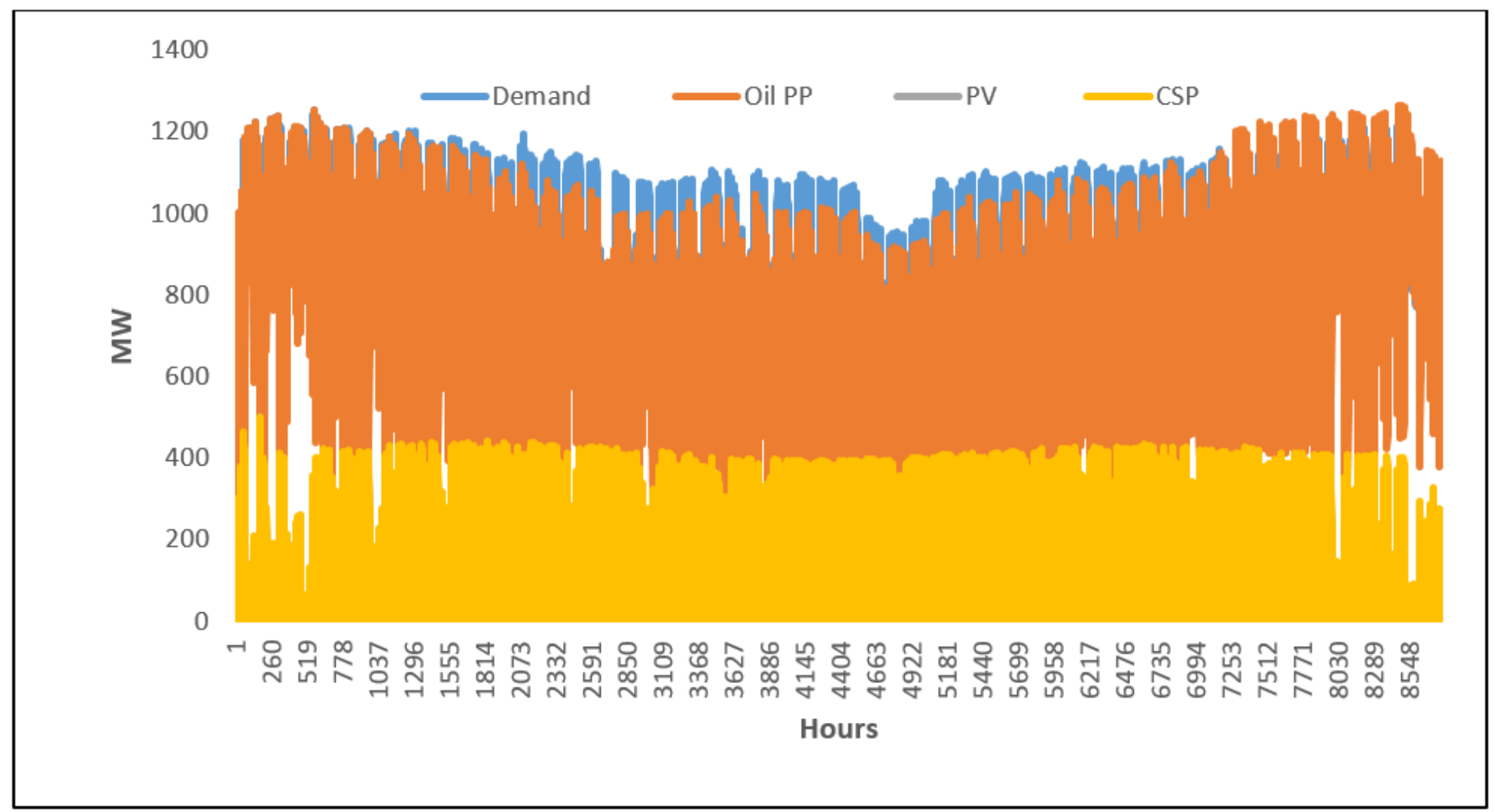

Figure 14 
Annual electricity demand and supply from PV, CSP and Oil power plants

\section{Figure 15}

Annual electricity demand and supply from CSP, Wind and Oil power plants

\section{Figure 16}

Hourly electricity profile for the $100 \%$ renewable energy technologies: (a) PV/Wind/30GW storage (b) Wind/CSP/30GW storage (c) Wind/PV/CSP/30GW storage

\section{Figure 17}

Hourly excess electricity export for PV/Wind/Storage

\section{Figure 18}

Annual electricity balance showing CEEP (PV/wind/Storage). 
$\mathrm{CO}_{2}$ emission reduction

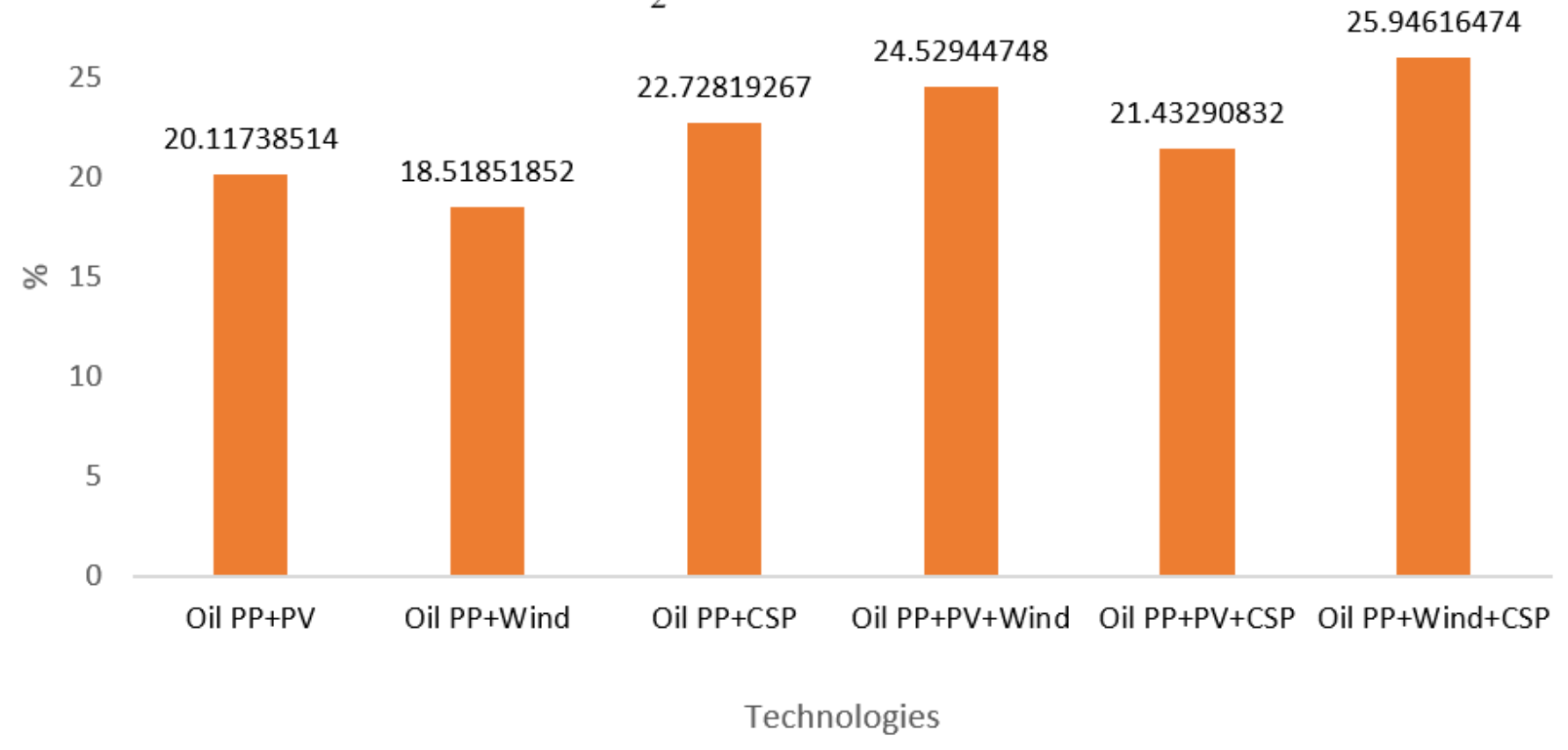

\section{Figure 19}

$\mathrm{CO}_{2}$ emission reduction as against reference scenario for RES and Oil power plants

Figure 20

Total annual cost for the different scenarios considered

\section{Supplementary Files}

This is a list of supplementary files associated with this preprint. Click to download.

- gRAPHICALABSTRACT.docx 